\title{
Journal of the American Board of Family Medicine Announces Completion of Archiving Project
}

Phillip Lupo, Jr., MLIS, Anne Victoria Neale, PhD, MPH, and Marjorie A. Bowman, MD, MPA

The Fournal of the American Board of Family Medicine $(A A B F M)$ is proud to announce the completion of a project to make all content available on our website. Mr. Phillip Lupo, our Senior Editorial Assistant, in collaboration with HighWire Press, managed this large endeavor, which involved scanning and uploading online all missing older issues (1988-2000), or approximately 6000 pages. An abstract and PDF version of each missing article is now available on the $\mathcal{F} A B F M$ website in our archive of online issues at: http://jabfm.org/content/by/ year. The entire $7 A B F M$ is now preserved for future generations of family medicine physicians and researchers. Enjoy!
Figure 2. Archive of the first JABFM volume from 1988. Data from the JABFM website, hosted by HighWire Press. Available from: http://jabfm.org/content/by/year/ 1988. Accessed January 9, 2014.

Archive of 1988 Online Issues

$\begin{array}{ll}\text { January } & 1988 \\ \text { January } 1: 1(1): 1-70 & \text { April } 1 ; 1(2): 75-149 \\ \text { July } & \text { October } \\ \text { July } 1: 1(3): 151-226 & \text { October } 1 ; 1(4): 227-302\end{array}$

Conflict of interest: The authors are editors and staff of the 7ABFM.

Figure 1. Archive of all JABFM articles. Data from the JABFM website, hosted by HighWire Press. Available from: http://jabfm.org/content/by/year. Accessed January 9, 2014.

\section{Archive of All Online Issues}

January 1988 - Present

Current Issue: January 1, 2014 Vol. 27, Num. 1
Recent Issues:

November 1, 2013 September 1, 2013 July 1, 2013 $\begin{array}{lll}\text { Vol. } 26, \text { Num. } 6 & \text { Vol. 26, Num. } 5 & \text { Vol. 26, Num. } 4\end{array}$

Full Text and Abstracts: January 2003 - Present

\begin{tabular}{|c|c|c|c|c|c|c|c|c|c|c|}
\hline $2010 s$ & 2010 & 2011 & 2012 & 2013 & 2014 & - & - & - & - & - \\
\hline $2000 s$ & - & - & - & 2003 & 2004 & 2005 & 2006 & 2007 & 2008 & 2009 \\
\hline
\end{tabular}

Full Text (PDF Format Only) and Abstracts: January 1988 - November 2002

\begin{tabular}{|c|c|c|c|c|c|c|c|c|c|c|}
\hline 2000s & 2000 & 2001 & 2002 & - & - & - & - & - & - & - \\
\hline $1990 s$ & 1990 & 1991 & 1992 & 1993 & 1994 & 1995 & 1996 & 1997 & 1998 & 1999 \\
\hline $1980 s$ & - & - & - & - & - & - & - & - & 1988 & 1989 \\
\hline
\end{tabular}

